HARMONY

\title{
KREATIVITAS DALAM PEMBELAJARAN PKN DAN IPS MASA NEW NORMAL: LEARNING MEDIA COMBINATION BERBASIS SOCIAL LEGACY
}

\author{
Ary Purwantiningsih ${ }^{1}$, Prayetno ${ }^{2}$, Ferani Mulianingsih ${ }^{3} \bowtie$ \\ Universitas Terbuka ${ }^{1}$, Universitas Negeri Medan ${ }^{2}$, Universitas Negeri Semarang ${ }^{3}$
}

\begin{tabular}{l} 
Info Artikel \\
\hline Sejarah Artikel: \\
Disubmit Agustus 2020 \\
Direvisi September 2020 \\
Diterima Oktober 2020 \\
\hline Keywords: \\
(Learning $\quad$ Media \\
Combination; New \\
Normal; Social Legacy; \\
Civics and Social Sciences \\
Learning)
\end{tabular}

Sejarah Artikel:

Disubmit Agustus 2020

Direvisi September 2020

Keywords:

(Learning

Media

Combination; New

Normal; Social Legacy;

Civics and Social Sciences

\begin{abstract}
Abstrak
Pengabdian masyarakat ini bertujuan untuk memberi bekal implementasi pembelajaran PKn dan IPS daring dirumah pada peserta didik jenjang Sekolah Menengah Pertama akibat dari adanya pandemik COVID-19. Pengabdian ini menggunakan analisis situasi dimana dalam mengumpulkan informasi data mengenai pembelajaran PKn dan IPS di tengah Pandemi Covid-19 yang relevan. Hasil dalam pengabdian kepada masyarakat, menunjukkan bahwa dampak COVID-19 terhadap pembelajaran daring PKn dan IPS di Sekolah Menengah Pertamabelum terlaksanakan dengan cukup baik. Hal ini dapat dilihat dari kesiapan implementasi pembelajaran daring PKn dan IPS di Sekolah Menengah Pertama, serta kreativitas dalam pembelajaran PKn dan IPS pada masa new normal yang dilaksanakan oleh guru harus ditingkatkan. Sedangkan dalam pembelajaran pada masa new normal sangat diperlukan kerjasama antara guru, peserta didik dan orang tua dalam belajar di rumah.
\end{abstract}

\begin{abstract}
The purpose of this community dedication is to provide provisions for the implementation of online Civics and Social Sciences learning at home in Junior High School students as a result of the COVID-19 pandemic. This dedication uses a situation analysis where in gathering the data information about Civics and Social Sciences learning in the middle of the relevant Covid-19 Pandemic. The result of community dedication showed that the impact of COVID-19 on Civics and Social Sciences online learning in Junior High School has not been implemented well enough. It can be seen from the readiness of the implementation of Civics and Social Sciences online learning in Junior High Schools, as well as creativity in learning Civics and Social Sciences during the new normal period carried out by teachers must be improved. While learning in the new normal period is very much needed collaboration between teachers, students and parents in learning at home.
\end{abstract}




\section{PENDAHULUAN}

Pada dasarnya setiap proses pembelajaran yang dilakukan diarahkan untuk mencapaitujuan yang telah ditentukan. Dalam proses pembelajaran terjadi interaksi antara berbagaikomponen, komponen-komponen pembelajaran itu dapat dikelompokkan dalam 3 kategoriyaitu: guru, materi ajar, dan siswa (Muhammad Ali, 2007). Peran pendidik sangat penting karena berfungsi sebagaipembimbing yang menyampaikan dan mentransfer bahan ajar berupa ilmu pengetahuanbegitu juga dengan peserta didik yang berperan sebagai penimba ilmu, sedangkan materi ajar yangdisampaikan oleh pendidik merupakan informasi atau pesan yang harus dipelajari oleh peserta didik untuk dipahami, dihayati, dan diamalkan sebagai bekal untuk menyelesaikan studinya kelak.

Semakin meluasnya penyebaran wabah Virus Corona Diseases 2019 (Covid-19) membuat pemerintah dan semua stake holder harus berfikir keras dalam menangani kasus ini.Sampai saat ini, pemerintah tidak mengambil langkah refresif seperti pembatasan wilayah secara ketat atau lockdown, tetapi hanya melakukan aturan pembatasan sosial atau Social Distancing.Hal ini diatur dalam UU No. 6 Tahun 2018 tentang Kekarantinaan Kesehatan yang kemudian dipertegas dengan PP No. 21 Tahun 2020 dan Permenkes 9 tahun 2020 tentang Pembatasan Sosial Berskala Besar (PSBB).

Presiden Joko Widodo dengan tegas mengimbau utntuk bekerja dari rumah, belajar dari rumah, dan ibadah dari rumah. Hal inilah membuat dunia pendidikan kita menjadi berubah 180 derajat. Karena satu satunya solusi yang bisa ditawarkan dengan melakukan pembelajaran daring (online learning/online classroom).

Hal ini seperti memberikan shock therapy bagi pendidik dan peserta didik. Banyak pendidik belum mengenal apa itu pembelajaran daring dan bagaimana melakukannya. Demikian pula dengan pula peserta didik masih belum familiar dengan pembelajaran daring. Memang selama ini dunia pendidikan kita seakan-akan acuh terhadap pembelajaran online dan sangat lambat perkembangannya di Indonesia.
Pembelajaran secara daring atau online learningsangat bergantung dengan koneksi jaringan internet yang menghubungkan antar perangkat guru dan para siswa.Pembelajaran daring ini sangat membantu dunia pendidikan kita di saat pandemi ini. Banyak aplikasi yang bias dimanfaatkan dalam pembelajaran daring seperti Whatsapp Group, Google Classroom, Edmodo, Quizzi, Zoom Cloud, Jitsi, dan lain sebagainya.

\section{METODE}

Pengabdian ini diawali dengan menemukan masalah mengenai perlunya media pembelajaran berbasis lokal untuk mendukung kualitas pembelajaran yaitu solusi pendidikan di era new normal: learning media combination berbasis social legacy dalam pembelajaran PKn dan IPS untuk menghadapi pula era revolusi industri 4.0. Khalayak sasaran dalam pengabdian ini yaitu mahasiswa Program Studi Pendidikan PKn Universitas Terbuka dan IPS FIS Unnes.

Prosedur kerja dalam pengabdian kepada masyarakat ini ada tiga tahap, yaitu:

1. Perencanaan kegiatan pengabdian, terdiri dari: (a) tudi lapangan mengenai permasalahan mitra pengabdian; (b) Penyusunan materi tentanglearning media combination berbasis social legacy dalam pembelajaran PKn dan IPS.

2. Tahap pelaksanaan terdiri dari: implementasi learning media combination berbasis social legacy dalam pembelajaran PKn dan IPS di era new normal.

3. Evaluasi hasil pelaksanaan pengabdian.

\section{PEMBAHASAN}

Kearifan lokal (local wisdom) dalam dekade belakangan ini sangat banyak diperbincangkan. Perbincangan tentang kearifan lokal sering dikaitkan dengan masyarakat lokal dan dengan pengertian yang bervariasi. Kearifan lokal merupakan gagasan-gagasan setempat (lokal) yang bersifat bijaksana, penuh kearifan, bernilai baik yang tertanam dan diikuti oleh anggota masyarakatnya (Sartini, 2004). Menurut rumusan yang dikeluarkan oleh Departemen 
Sosial (sekarang Kementerian Sosial) kearifan lokal diartikan sebagai pandangan hidup dan pengetahuan serta berbagai strategi kehidupan yang berwujud aktivitas yang dilakukan oleh masyarakat lokal dalam menjawab berbagai masalah dalam pemenuhan kebutuhan mereka (Departemen Sosial RI, 2006). Sistem pemenuhan kebutuhan mereka pasti meliputi seluruh unsur kehidupan, agama, ilmu pengetahuan, ekonomi, teknologi, organisasi sosial, bahasa dan komunikasi, serta kesenian.

Paradigma pembelajaran berpusat pada aktivitas peserta didik (Sanjaya, 2016) memungkinkan perguruan tinggi untuk melakukan perkuliahan dengan tingkat fleksibilitas berbeda dengan pendidikan dasar. Mahasiswa merupakan subyek pembelajaran yang dapat dikoordinasikan/dimobilisasikan untuk mengembangkan kemampuan independensi dalam belajarnya. Terlepas dari independensinya dalam belajar, dosen yang dalam hal ini menjadi tidak hilang peran sentralnya dalam perkuliahan. Hubungan antara mahasiswa dengan dosen dalam pembelajaran berorientasi pada aktivitas peserta didik membentuk pola kemungkinan. Pola tersebut merupakan gejala/baru sebagai hasil relasi sinergis yang selanjutnya memunculkan hibrida paradigma baru yakni dosen sebagai mitra belajar mahasiswa dan mahasiswa sebagai mitra kerja dosen dalam pembelajaran.

Pembelajaran merupakan aktivitas yang tidak terbatas ruang dan waktu secara absolut. Khususnya mahasiswa, belajar dapat berlangsung di mana saja dan kapan saja yang dalam ini perkuliahan mereka tidak hanya berlangsung di ruang kelas dengan durasi pembelajaran yang sudah ditentukan. Mereka dapat melakukan aktivitas luar kelas yang dapat menunjang pencapaian tujuan pembelajaran mereka. Salah satunya adalah dengan learning media combination berbasis social legacy melalui kegiatan pembelajaran PKn dan IPS di tengah Pandemi Covid-19.

World Health Organization (WHO) telah menetapkan virus Corona atau COVID-19 sebagai pandemi karena telah menyebar ke lebih dari 100 negara di dunia. Menurut KBBI Online, pengertian pandemi yaitu wabah yang berjangkit serempak di mana-mana, meliputi daerah geografi yang luas (https://kbbi.kemdikbud.go.id/). Berdasarkan data dari Kementerian Kesehatan RI tanggal 21 Juni 2020 dapat dilihat pada Gambar 1 berikut ini.

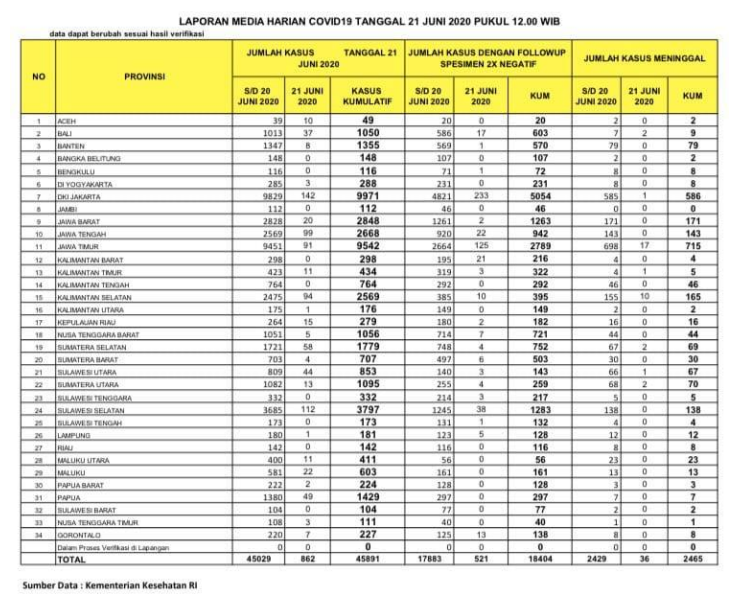

Gambar 1. Data Informasi Coronavirus (Covid-19) Sumber: Kementerian Kesehatan RI, Update 21 Juni 2020

Berdasarkan data kasus Covid-19 di Indonesia meningkat. Pemerintah masih menerapkan PSBB. Kebijakan ini dilakukan untuk menekan angka penyebaran COVID-19 yang belum menunjukkan grafik penurunan. Beberapa universitas dan sekolah meminta seluruh mahasiswa dan peserta didik untuk melaksanakan pembelajaran di rumah. Dampak pandemi corona merambah dunia pendidikan, pemerintah pusat hingga daerah memberikan kebijakan untuk meliburkan seluruh lembaga pendidikan. Hal ini dilakukan sebagai upaya mencegah meluasnya penularan virus corona. Adapun penghentian kegiatan di sekolah/institusi pendidikan lainnya diarahkan untuk dapat beralih menjadi pembelajaran jarak jauh dari tempat tinggal masing-masing dan menggunakan media yang paling efektif.

Kehidupan new normal di sekolah dan kampus dinilai mesti diatur secara rinci dengan melibatkan sumber daya yang tak sedikit. Hal ini dianggap penting mengingat orang tua dan peserta didik mulai gelisah dengan sistem belajar 
dari rumah sementara pandemi Covid-19 belum juga reda dan vaksin belum ditemukan.

Pendidikan merupakan sarana terpenting untuk mewujudkan kemajuan bangsa dan negara, hal ini karena pendidikan merupakan proses budaya yang bertujuan untuk meningkatkan harkat dan martabat manusia. Dalam Undang-undang Republik Indonesia No. 20 Tahun 2003 tentang Sistem Pendidikan Nasional Bab I Pasal 1 dinyatakan bahwa Pendidikan merupakan usaha sadar dan terencana untuk mewujudkan suasana belajar dan proses pembelajaran agar peserta didik secara aktif mengembangkan potensi dirinya untuk memiliki kekuatan spiritual keagamaan, pengendalian diri, kepribadian, kecerdasan, akhlak mulia, serta keterampilan yang diperlukan dirinya, masyarakat, bangsa, dan Negara. Artinya, pendidikan di sekolah merupakan proses yang terencana dan mempunyai tujuan, sehingga segala sesuatu yang dilakukan oleh guru dan peserta didik dapat mencapai tujuan pembelajaran. Melalui proses pendidikan terencana diarahkan untuk mewujudkan suasana belajar yang kondusif serta proses belajar yang menyenangkan, dengan tujuan peserta didik dapat mengembangkan potensi diri.

Melihat tujuan dari pendidikan nasional tersebut, maka efektivitas pembelajaran harus ditingkatkan, karena proses pembelajaran memegang peran penting dalam menghasilkan atau menciptakan lulusan yang berkualitas. Oleh karena itu, perlu mendapatkan perhatian yang lebih serius dari stakeholders untuk menciptakan kegiatan proses pembelajaran yang menyenangkan dan efektif. Salah satu usaha yang dapat dilakukan adalah pembaruan model pembelajaran yang dapat menyentuh kemampuan peserta didik dalam aspek kognitif, afektif maupun psikomotorik. Misalnya, model pembelajaran yang membiasakan peserta didik untuk aktif, sehingga peserta didik dapat mengembangkan seluruh kemampuan untuk bisa belajar secara mandiri dengan melihat isu-isu yang konvensional dalam kehidupan sehari-hari.

Pendidikan PKn dan IPS mempunyai peran yang sangat penting sebagai wahana untuk mengembangkan kemampuan atau potensi peserta didik untuk berfikir kritis menanggapi isuisu atau permasalahan yang ada. Oleh karena itu, untuk mendorong kemampuan yang telah dimiliki oleh peserta didik, maka diperlukan penerapan model pembelajaran yang menghasilkan karya berbasis masalah untuk membangkitkan motivasi belajar dan hasil belajar peserta didik melalui pemecahan masalah yang terjadi di kehidupan sehari-hari. Model pembelajaran berbasis masalah merupakan suatu pendekatan pembelajaran yang menggunakan masalah dalam kehidupan sehari-hari sebagai suatu konteks bagi peserta didik untuk belajar tentang cara berpikir kritis, keterampilan pemecahan masalah, dan untuk memperoleh pengetahuan serta konsep dari materi pelajaran yang disampaikan.

Paradigma student centered melibatkan mahasiswa/peserta didik dalam proses pemahaman konsep-konsep, pembelajar bukan lagi yang membuat siswa mengerti akan konsep tersebut. Dalam strategi pembelajaran Konvensional yang masih menggunakan paradigma teacher centered seperti tipe ceramah dan tanya jawab, penekanan ada pada cara menyampaikan pengetahuan oleh pembelajar kepada siswa bukan dilihat dari sisi mahasiswa/peserta didik sebagai subjek yang belajar. Materi pelajaran yang disampaikan terbatas pada apa yang diberikan di depan kelas dan siswa akan menyerap pada saat itu saja secara pasif dan tidak mengembangkan sendiri pengetahuan tersebut. Pendekatan semacam ini tidak terlalu efektif karena konsentrasi mahasiswa/peserta didik pada saat ceramah tidak mungkin seratus persen dan tahan lama. Banyak hal yang terlewatkan dalam belajar dengan tipe ceramah terutama karena pembelajar bertindak aktif memberi, sedang mahasiswa/peserta didik pasif menerima. Biasanya pengetahuan semacam ini tidak mempunyai ketahanan. Oleh karena itu diperlukan penggunaan beragam tipe pembelajaran yang memungkinkan siswa terlibat aktif dalam pembelajaran.

Fungsi dari teknologi dalam dunia pendidikan berguna untuk memecahkan masalah pembelajaran untuk dapat membantu 
mahasiswa/peserta didik agar lebih memahami materi secara konkret. Teknologi dalam dunia pendidikan mempunyai fungsi untuk membantu mempermudah proses penyampaian kepada mahasiswa/peserta didik agar lebih efektif dan efesien dengan berbantuan sebuah media dalam proses pembelajarannya. Teknologi dapat membantu untuk membuat media penunjang yang bertujuan pengajar memberikan gambaran dari materi yang masih sulit diserap oleh mahasiswa/peserta didik (abstrak) ke arah yang lebih dapat dipahami (konkret) sehingga mencapai kompetensi yang diharapkan. Sehingga, pembelajaran yang mengarah pada student centered dapat mudah dicapai.

Rooney menyebutkan bahwa "Blended learning is a hybrid learning concept integrating traditional inclass sessions and e-Learning elements" (Rooney, 2003). Menurutnya, antara blendedlearning merupakan bagian dari konsep hybridlearning yang mengkombinasikan metode pembelajaran tatap muka dengan pembelajaran online. Definisi ini masih terlalu umum dalam menjelaskan pengertian blended learning.

Ahli teori pendidikan sering menyebut Pendidikan Era Revolusi Industri 4.0 untuk menggambarkan berbagai cara mengintegritaskan teknologi cyber baik secara fisik maupun non fisik dalam pembelajaran. Pendidikan Era Revolusi Industri 4.0 adalah fenomena yang merespons kebutuhan revolusi industri dengan penyesuaian kurikulum baru sesuai situasi saat ini. Kurikulum tersebut mampu membuka jendela dunia melalui genggaman contohnya memanfaatkan internetofthings (IoT). Di sisi lain pengajar juga memperoleh lebih banyak referensi dan metode pengajaran.

Covid-19 yang lebih dikenal dengan nama virus Corona adalah jenis baru dari coronavirus yang menular ke manusia. Virus ini menyerang sistem pernapasan. Penyakit karena infeksi virus ini disebut Covid-19. Virus Corona bisa menyebabkan gangguan pada sistem pernapasan, pneumonia akut, sampai kematian. Indonesia saat ini tengah menghadapi hari-hari melawan covid-19, bahkan Menteri Pendayagunaan Aparatur Negara dan Reformasi Birokrasi
(Menteri PAN-RB) telah mengeluarkan surat edaran baru yang pada intinya menyatakan perpanjangan masa bekerja dari rumah (WorkFromHome) dan penyesuaian sistem kerja.

Tentu penyesuaian diperlukan dalam menerapkan Pendidikan era Revolusi 4.0. Akan tetapi tidak dapat dipungkiri adanya wabah Covid-19 menjadi salah satu pendorong penerapan sistem ini. Di sisi lain selain dituntut memahami teknologi dan informasi serta cara mengimplementasikannya, tentu terdapat permasalahan yang timbul yaitu terkait sarana prasarana yang memadai.

Surat Edaran (SE) yang dikeluarkan pemerintah pada 18 Maret 2020 segala kegiatan didalam dan diluar ruangan di semua sektor sementara waktu ditunda demi mengurangi penyebaran corona terutama pada bidang pendidikan. Pada tanggal 24 maret 2020 Menteri Pendidikan dan Kebudayaan Republik Indonesia mengeluarkan Surat Edaran Nomor 4 Tahun 2020 Tentang Pelaksanaan Kebijakan Pendidikan Dalam Masa Darurat Penyebaran COVID, dalam Surat Edaran tersebut dijelaskan bahwa proses belajar dilaksanakan di rumah melalui pembelajaran daring/jarak jauh dilaksanakan untuk memberikan pengalaman belajar yang bermakna bagi siswa. Belajar di rumah dapat difokuskan pada pendidikan kecakapan hidup antara lain mengenai pandemi Covid-19.

Menurut Zhao (2003) Tinjauan literatur saat ini telah menemukan bahwa ada banyak penelitian tentang implementasi teknologi dalam pendidikan online berkaitan dengan penghematan biaya dan efisiensi, bahwa peningkatan kualitas dan efektivitas pendidikan online memerlukan kerangka kerja yang harus diterapkan di sekolah .Kerangka yang diusulkan memberikan panduan praktis kepada para pemangku kepentingan dalam penilaian kualitas pengajaran dan pembelajaran online. Menurut Chakraborty (2014) mengungkapkan beberapa faktor yang dapat menciptakan pengalaman belajar yang menarik bagi pembelajar online.

Learning media combination berbasis sociallegacy dalam pembelajaran PKn dan IPS ini yaitu mengkolaborasi antara pembelajaran online 
dangan kearifan lokal. Dengan munculnya pandemik COVID-19 kegiatan belajar mengajar yang semula dilaksanakan di kampus dan sekolah kini menjadi belajar di rumah melalui daring. Belajar daring (online) dapat menggunakan teknologi digital seperti google classroom, rumah belajar, zoom, video converence, telepon atau livechat dan lainnya.

\section{SIMPULAN}

Persebaran virus Corona yang massif di berbagai negara, memaksa kita untuk melihat kenyataan bahwa dunia sedang berubah. Kita bisa melihat bagaimana perubahan-perubahan di bidang teknologi, ekonomi, politik hingga pendidikan di tengah krisis akibat Covid-19. Perubahan itu mengharuskan kita untuk bersiap diri, merespon dengan sikap dan tindakan sekaligus selalu belajar hal-hal baru. Indonesia tidak sendiri dalam mencari solusi bagi peserta didik agar tetap belajar dan terpenuhi hak pendidikannya.

Karena pada hakikatnya proses belajar adalah proses komunikasi (proses penyampaian pesan) yang harus diwujudkan melaui kegiatan penyampaian dan tukar menukar pesan atau informasi oleh setiap dosen dan mahasiswa. Pesan atau informasi dapat berupa pengetahuan, keahlian, skill, ide, pengalaman dan sebagainya. Melalui proses komunikasi, pesan atau informasi dapat diserap dan dihayati oleh orang lain. Di masa pandemi ini jelas muncul kecenderungan pemanfaatan/pendayagunaan software. Software (perangkat lunak komputer) adalah program yang dirancang untuk membuat, merekayasa, atau mengembangkan berbagai hal secara digital. Kemampuan untuk menggunakan beragam perangkat lunak mutlak dimiliki oleh mahasiswa masa kini agar dapat melakukan pembelajaran daring serta lebih mudah menyesuaikan diri dengan kemajuan teknologi.

Dampak covid-19 sangat terlihat jelas terutama pesatnnya penggunaan beberapa software (perangkat lunak komputer) bagi proses pembelajaran kampus. Kebijakan pembelajaran daring juga membuat perusahaan-perusahaan software berlomba-lomba memberikan fasilitasfasilitas komunikasi untuk menunjang aktifitas pembelajaran di rumah. Tidak hanya mahasiswa, para dosen juga berusaha memberikan pembelajaran yang menarik dan efektif demi memenuhi kewajibannya secara maksimal. Banyak dosen yang menggunakan software (perangkat lunak) yang menunjang proses pembelajaran daring, diantaranya google classroom, zoom, google meet, serta aplikasi lainnya.

Di tengah pandemi Covid-19 ini, sistem pendidikan kita harus siap melakukan lompatan untuk melakukan transformasi pembelajaran PKn dan IPS daring bagi semua mahasiswa dan oleh semua pendidik. Kita memasuki era baru untuk membangun kreatifitas, mengasah skillmahasiswa, dan peningkatan kualitas diri dengan perubahan sistem, cara pandang dan pola interaksi kita dengan teknologi. Pendidikan saat ini tidak bisa terlepas dari revolusi industri 4.0 yang berkembang di berbagai negara. Untuk itu, pendidikan dalam jaringan (daring/online) seharusnya bisa diteruskan sebagai pelengkap setelah pandemi Covid19.Informasi yang begitu cepat disertai perkembangan teknologi yang kian pesat membuat pendidikan di Indonesia berubah setelah pandemi Covid-19.

Merebaknya wabah Covid-19, Pendidikan era Revolusi Industri 4.0 dapat diterapkan dengan penyesuaian tertentu tanpa mennyampingkan hal-hal yang perlu diperhatikan lebih teknis, misalnya dampak dan kelemahannya. Di sisi lain tuntutan peran mahasiswa dan peserta didik diharapkan mampu membawa perubahan positif di tengah situasi melalui penerapan solusi pendidikan di era new normal: Learning media combination berbasis social legacy.

\section{DAFTAR PUSTAKA}

Chakraborty, M. and Muyia Nafukho, F. 2014, "Strengthening student engagement: what do 
students want in online courses?". European Journal of Training and Development. Vol. 38 No. 9 9, pp. 782-802. https://doi.org/10.1108/EJTD-11-2013-0123

Departemen Sosial RI. 2006. Memberdayakan Kearifan Lokal bagi Komunitas Adat Terpencil. 111-120.

Kementerian Kesehatan RI, Update 21 Juni 2020

Muhammad Ali, Guru dalam Proses Belajar Mengajar, (Bandung: Sinar Baru Algensindo, 2007), h

PP No. 21 Tahun 2020 dan Permenkes 9 tahun 2020 tentang Pembatasan Sosial Berskala Besar (PSBB)

Rooney, J. E. 2003. Blended learning opportunities to enhance educational programming and meetings. Association Management, 55(5), 2632
Sanjaya, W. 2016. Strategi Pembelajaran. Jakarta: Kencana Prenada Media Group.

Sartini. 2004. Menggali Kearifan Lokal Nusantara: Sebuah Kajian Filsafat. Jurnal Filsafat. 37,

Surat Edaran Nomor 4 Tahun 2020 Tentang Pelaksanaan Kebijakan Pendidikan Dalam Masa Darurat Penyebaran COVID

Undang-undang Republik Indonesia No. 20 Tahun 2003 tentang Sistem Pendidikan Nasional

UU No. 6 Tahun 2018 tentang Kekarantinaan Kesehatan

Zhao, F. 2003. "Enhancing the quality of online higher education through measurement". Quality Assurance in Education. Vol. 11 No. 4, pp. 214221.

https://doi.org/10.1108/09684880310501395 